\title{
Sealing, whaling and krill fishing in the Southern Ocean: past and possible future effects on catch regulations
}

\section{Robert J. Hofman}

US Marine Mammal Commission, 4340 East-West Highway, Room 700, Bethesda, Maryland 20814, USA (bhofman@mmc.gov)

Received February 2016; first published online 28 November 2016

ABSTRACT. This paper (1) reviews the history of sealing and whaling in the Southern Ocean to illustrate how market demands combined with no or ineffective regulation of catches led to the overexploitation and near extinction of southern fur seals, southern elephant seals and all but one of the Southern Ocean populations of large whales; (2) indicates how the overexploitation and depletion of krill-eating whales led to the Krill Surplus Hypothesis, and the development of the Antarctic krill fishery and the Convention on the Conservation of Antarctic Marine Living Resources (CCAMLR); (3) points out how misinterpretation of the reference to 'rational use' in CCAMLR Article II(2), combined with consensus decision-making and the potential growth of markets for Antarctic krill, could lead to ineffective regulation of the krill fishery and adverse effects on the krill resource, on recovery of depleted populations of krill-dependent whales, and on other ecologically related species and populations; and (4) identifies reasonable actions that could be taken cooperatively by the International Whaling Commission and the CCAMLR Commission to minimise the risk that the krill fishery will prevent or impede recovery of depleted populations of krill-dependent whales.

\section{Antarctic seals and sealing}

On 13 July 1772, Captain James Cook's ships Adventure and Resolution sailed from Portsmouth, England, on his second voyage to search for the fabled southern continent, Tierra Australis Incognito. He returned to England in 1775. In his logs of the voyage, published in 1777 , Cook noted the abundance of fur seals on the beaches and whales in the adjacent waters of South Georgia, where he landed, and named and claimed for England on 17 January 1775 (Beaglehole 1955). At that time, sealers and whalers, mostly from England and New England, USA, were hunting seals on the beaches and whales in the adjacent waters of the Falkland Islands, Tierra del Fuego, and both the Atlantic and Pacific coasts of Patagonia (Stackpole 1953).

In 1778, the first sealers reached South Georgia (Bonner 1964; Bonner and Laws 1964). During the 1801/02 austral summer, a single vessel, in a fleet of more than 30 , took 57,000 Antarctic fur seals (Arctocephalus gazella Peters) from South Georgia and nearby islands (Bonner 1958). By 1822 an estimated 1,200,000 fur seals had been killed and the species was nearly extinct on South Georgia and adjacent islands (Weddell 1825 cited in Bonner 1958). Whalers were also attracted to South Georgia, and both sealers and whalers often hunted southern elephant seals (Mirounga leonina L.) for the oil in their blubber (Murphy 1947 cited in Bonner 1958).

In early 1819, William Smith, the captain of a British merchant ship blown south while transiting Cape Horn, sighted what was subsequently named King George Island. Later that year, Smith returned, landed on the island and claimed it for England. The next year, the British Royal Navy sent a ship, captained by Edward Bransfield and piloted by Smith, to survey the island. They found a group of islands, subsequently named the South Shetland
Islands, and returned with a large cargo of fur seal skins. Word spread rapidly and soon dozens of sealers were searching for and exploiting fur seal colonies throughout the Antarctic and sub-Antarctic islands. By the end of 1822, virtually all of the Antarctic fur seals colonies had been found and reduced to zero or near zero (Weddell 1825 cited in Landis 2001).

In 1909, the British Falkland Island Dependencies (FIDs) administration prohibited the taking of fur seals and regulated the taking of elephant seals at South Georgia (Bonner and Laws 1964; Bonner 1984). By the 1950s, viable colonies of both species were present and growing on South Georgia, and the South Shetland, South Sandwich and South Orkney islands (Bonner 1964). In 1964, the Antarctic Treaty Consultative Parties (ATCPs) afforded special protection to the Antarctic fur seal as part of the Agreed Measures for the Conservation of Antarctic Flora and Fauna. By the early 2000s, there were an estimated 4-6 million Antarctic fur seals and, while still increasing, the species no longer required special protection (SCAR 2006). Also, by the early 2000s, southern elephant seals numbered circa 650,000 individuals. Although there have been significant unexplained declines in subpopulations in the Pacific and Indian oceans over the past 40 years, the population size presently seems relatively stable (SCAR 1991; Laws 1994; Boyd and others 1996).

\section{The Convention for the Conservation of Antarctic Seals}

The Antarctic crabeater seal (Lobodon carcinophagus Hombron \& Jacquinot) is the most abundant seal in the world (Erickson and Hofman 1974; Laws 1977). Consequently, when overexploitation and corresponding declines in North Atlantic populations of harp seals 
(Pagophilus groenlandicus Erxleben) and hooded seals (Cystophora cristata (Erxleben)) occurred in the late 1950s and early 1960s, consideration was given to diverting some of the Norwegian and Canadian sealing fleets to the Antarctic (Sergeant 1963; Sergeant 1965). In September/October 1964, a private Norwegian expedition conducted research and an experimental hunt for seals in the pack ice of the southwest Atlantic sector of the Southern Ocean. A total of 322 seals were taken: 218 crabeater seals, 84 leopard seals (Hydrurga leptonyx (Blainville)), 15 Ross seals (Ommatophoca rossi (Gray)), four elephant seals and one fur seal (Øritsland 1970).

Concerned about the possible unregulated exploitation of the Antarctic pack ice seals, in 1966 the ATCPs requested the Scientific Committee on Antarctic Research (SCAR) to provide information on the distribution and abundance of the four ice seal species, their possible sustainable take levels and optimal arrangements for regulating a commercial sealing industry in the Antarctic should it develop. The SCAR Working Group on Biology subsequently established a group of specialists on seals to consider the request. The group's findings and recommendations were forwarded to the ATCPs in 1968 (Anonymous 1970).

Following receipt of those findings and recommendations, the ATCPs undertook development of a regulatory regime to govern commercial sealing in the Antarctic should it occur. The Convention for the Conservation of Antarctic Seals (CCAS) was concluded in 1972 and entered into force in 1978. It provides that the Contracting Parties may establish a commission to regulate the industry at any time after commercial sealing has begun. It also provides that a scientific advisory body may be established at the same time to assess and monitor the status of the affected seal populations and to advise the commission of needed conservation measures.

The CCAS included an annex that sets forth conservative catch levels for each species, open and closed seasons, open and closed areas, and other measures to ensure that a developing sealing industry would not have significant adverse effects pending establishment of a regulatory commission and scientific advisory body. The CCAS recognised the need for scientific research, the possible indispensable use of seals for human and dog food by Antarctic research and support personnel, and the use of seals for museum specimens and educational purposes. Therefore, it authorised the Contracting Parties to issue permits to their nationals to kill or capture limited numbers of seals for those purposes. It required that parties issuing permits inform the other parties and SCAR of the actions authorised by the permits, and to subsequently report the species and numbers of seals killed and captured. Further, the CCAS invited SCAR to assess the catch and related information reported by the parties to identify and recommend any additional data that should be collected and reported, and to suggest changes in the conservation measures set forth in the CCAS annex if there are indications that catches or related activities are having harmful effects.

The CCAS is unique for three reasons: (1) it was the first international agreement to provide for regulating the commercial taking of a marine living resource before a modern industry began; (2) it was the first of the subsidiary, free-standing agreements negotiated by the ATCPs that now form what is known as the Antarctic Treaty System; and (3) unlike the consensus decisionmaking mandated by the Antarctic Treaty and other components of the Treaty System, decision-making under CCAS is by a simple two-thirds majority of the parties.

Although the former Soviet Union undertook an experimental sealing expedition in 1986/87 (Anonymous 1988), a commercial sealing industry has not developed in the Antarctic. Also, the 1991 Protocol to the Antarctic Treaty on Environmental Protection banned dogs in the treaty area so seals were no longer being killed for dog food.

\section{Southern Ocean whales and whaling}

By the 1790s, whaling vessels from the UK and the newly independent US were rounding Cape Horn to hunt sperm whales (Physeter macrocephalus L.) and southern right whales (Eubalaena australis (Desmoulins)) in the Pacific Ocean. Within 50 years, all sperm whale and right whale breeding and feeding grounds in the Pacific and Indian oceans were discovered. The whaling vessels operated under sail and the whales were pursued in small open boats and killed with hand thrown harpoons. Although the presence of whales around South Georgia and the South Sandwich Islands had been reported by Cook in 1777 , and in the Ross and Weddell seas by Sir James Clark Ross in the 1840s (Ross 1847), significant whaling did not commence in those areas until the late 1800s and early 1900s following the development of steam-powered ships and cannon-fired exploding harpoons.

The first documented attempts at whaling in the Antarctic were in the 1890 s when four steam-powered Scottish whalers and a Norwegian whaler hunted right whales in the eastern Weddell Sea, and Antarctic, a Norwegian whaling ship, hunted right whales in the Ross Sea (Landis 2001). The search for right whales was unsuccessful because by that time their calving and breeding grounds in the coastal waters of South America, New Zealand, Australia and South Africa had been discovered and the whales hunted to near extinction. However, the whalers found large numbers of the faster swimming blue (Balaenoptera musculus L.), fin (B. physalus L.), sei (B. borealis Lesson) and humpback (Megaptera novaeangliae Borowski) whales in both areas.

Successful, large-scale whaling in the Southern Ocean was initiated in 1904 by Carl Anton Larsen, a Norwegian sealer and whaler, who obtained authorisation from the British government to establish Grytviken, the first landbased whaling station, on South Georgia. Subsequently, in 1908, the British established a formal claim to the 
FIDs - South Georgia and the South Orkney, South Sandwich and South Shetland islands. Word of Larsen's success spread rapidly, and by 1912 the British had granted leases to six more companies for land-based whaling at South Georgia. Some of the lessees simply anchored a factory ship in one of the island's protected bays and used steam-powered catcher boats to hunt and bring the whales they killed to the factory ships for processing. Others established land-based processing facilities similar to those at Grytviken. Initially, the whales killed were towed to the factory ships and land-based stations where the blubber was removed for processing and the remaining carcasses discarded nearby. Barrett-Hamilton's hand-written 1914 journal (reprinted in Hollenberg 2008) provides a firsthand account of these operations. Recognising the waste and the likely adverse effects of unregulated whaling around South Georgia, the British FID's Administration established limits on the number of catcher boats that could be used and required that the whales killed be utilised completely.

While the British granted leases for only seven whale processing facilities on South Georgia, latecomers anchored factory ships and operated steam-powered catcher boats from protected bays along the Antarctic Peninsula and in the South Shetland, South Sandwich and South Orkney islands. By the 1912/13 austral summer, 62 catcher boats were hunting and delivering whales to factory ships in those areas. In that year alone, 10,760 whales were killed there, nearly four times the number killed that year in the traditional Northern Hemisphere whaling grounds.

In 1923, Carl Anton Larsen successfully initiated hunting of blue and fin whales in the southern Ross Sea using five catcher boats and an 8,223 ton factory ship named Sir James Clark Ross (Villiers 1925; Francis 1990; Ainley 2010). Until the stern slipway was developed the larger whales could not be hauled aboard the anchored factory ships. Therefore, they were tied to the sides of the factory ships while the blubber was removed and the carcasses were cut loose (Jackson 1978 cited in Francis 1990). When the last two whaling stations closed in 1965 , 175,250 whales had been removed from the waters around South Georgia: 41,515 blue whales, 87,555 fin whales, 26,754 humpback whales, 15,128 sei whales and 3,716 sperm whales (Ommanney 1971; Francis 1990; Landis 2001; Poncet and Crosbie 2005; Rubin 2008).

The first factory ships with stern slipways and on board processing capability arrived in the Antarctic in 1925. This enabled pelagic whaling, without the need to anchor factory ships in protected areas for processing. By 1931, 41 factory ships with stern slipways and 205 catcher boats were engaged in open-ocean whaling in the Southern Ocean (Tønnessen and Johnson 1982 cited in Francis 1990). In 1930/31 alone, 37,438 whales, including a record 29,400 blue whales, were killed in the Southern Ocean (Small 1971 cited in Francis 1990). By then it was apparent to many that such take levels could not be sustained.

\section{Regulatory efforts}

As noted previously, the British FID's government attempted to regulate the number of whales being killed in the waters around South Georgia by limiting the number of processing facilities and the number of catcher boats that could be employed. In 1929, Norway enacted domestic legislation recognising the need to regulate pelagic whaling in the Antarctic and elsewhere. The legislation, the Norwegian Whaling Act of 1929, prohibited Norwegian whalers from killing right whales, and the calves and females with calves of other species. It also established minimum sizes for the species permitted to be hunted, required factory ships to carry inspectors to record and report the species, numbers, sizes and other information regarding the whales killed and processed, and established a committee - the forerunner of the Bureau of International Whaling Statistics - to compile and annually publish summaries of the reported information (Tønnessen and Johnson 1982).

By the late 1800s, kerosene and other products from petroleum first extracted from wells in Pennsylvania in 1859 had begun affecting the markets for whale oil. The record Antarctic whale catches in 1930/31 flooded the whale oil market and caused a price collapse. Even before then it had been apparent to the whaling industry that national regulations were insufficient and that some kind of international regulation was necessary to control catches and sustain whale oil prices. Consequently, in 1925 the League of Nations, established post-World War I, appointed a committee of experts to assess possible ways for regulating the industry. Subsequent discussions led to the 1931 Geneva Convention for the Regulation of Whaling. The convention, patterned after the 1929 Norwegian Whaling Act, entered into force in January 1935. It prohibited the taking of both right whales, and the calves and females with calves of the other large whales. It called for the licensing of all whaling vessels and payment of gunners and crews to be based on the size and value rather than the number of whales killed. It had no provisions for enforcement and, because not all countries whose vessels were whaling in the Antarctic signed the convention, it had little effect on the taking of whales in the Antarctic (Francis 1990; Gambell 1993).

In 1937, delegates from many of the whaling nations met in London to consider how to overcome the shortcomings in the Geneva Convention. Among other things, the resulting International Agreement for the Regulation of Whaling set minimum sizes for taking of blue and fin whales, and established a three-month Antarctic whaling season - 8 December to 7 March. It established no limits on the number of whales that could be taken. The following year (1938) further discussions culminated in the adoption of a Protocol to the London Agreement that prohibited the taking of humpback whales in the Antarctic, and established a whale sanctuary in the Pacific sector of the Southern Ocean between $70^{\circ} \mathrm{W}$ and $160^{\circ} \mathrm{W}$. Again, no agreement could be reached on the number 
of whales that could be killed (Francis 1990; Gambell 1993). Consequently, both catches and the number of factory ships and catcher boats operating in the Antarctic and elsewhere continued to increase. In 1937/38, more than 50,000 whales were taken, most in the Antarctic, the largest yearly catch to that time (Tønnessen and Johnson 1982 cited in Francis 1990).

In the early 1900s, a German scientist, Wilhelm Normann, had developed a hydrogenation process to convert a variety of oils into semi-solids. During the Great Depression prior to World War II and in the years following the war, hydrogenation of whale oil was used to produce margarine, soap and other products, once more increasing the price of whale oil. Most pelagic whaling stopped during the war. Many factory ships and catcher boats were converted for war use and were lost during the war. In February 1944, while the war was still ongoing, representatives of seven allied countries with post-war whaling interests met in London to consider ways to strengthen the 1937 London Agreement and the 1938 Protocol. The resulting 1944 Protocol established catch limits expected to be well below the numbers of whales killed annually in the Antarctic prior to the war. However, instead of providing for the establishment of quotas for individual species and stocks, the protocol established the Blue Whale Unit (BWU) as a means for establishing a cap on the amount of whale oil that could be derived from the combined catches of all species. The BWU was the amount of oil that could be obtained from an average blue whale, and where two fin whales, two and a half humpback whales or six sei whales were judged to be equivalent to one BWU. The catch limit set for the 1946/47 whaling season was 16,000 BWUs. Practically, this meant that whalers could take up to 16,000 blue whales, 32,000 fin whales, 40,000 humpback whales, 96,000 sei whales, or some combination of the four (Francis 1990; Gambell 1993).

The current era of regulation was initiated in December 1946 with the signing of the International Convention for the Regulation of Whaling (ICRW) in Washington, DC. Like the earlier regulatory agreements, the focus was on sustaining the whaling industry, not the whales. That is, its objective, as stipulated in the Chapeau, was to "provide for the proper conservation of whale stocks and thus make possible the orderly development of the whaling industry' (ICRW Chapeau). Among other things, it provided for the establishment of the International Whaling Commission (IWC) to implement its provisions, established a Schedule of Agreed Regulatory Measures, and provided that the schedule could be amended by a three-quarter majority vote of its members. It also provided that members who objected to amendments of the schedule within 90 days of their adoption would not be bound by them. It did not limit or provide a means for limiting the number of factory ships or catcher boats that could be employed. It also did not require or provide a means for allocating catch quotas among the whaling nations or their whaling fleets. The text of the ICRW and amendments to the schedule adopted through the 1998 IWC meeting are provided in the Marine
Mammal Commission (MMC) (MMC 1994; MMC 1997; MMC 2000).

The IWC met for the first time in September 1949. From its start up until 1972 (see below), the BWU was used as the basis for setting catch limits. Although anticipated that the pause in whaling during WWII would have allowed recovery of the depleted blue whale populations and those of other heavily exploited large whales in the Antarctic, this proved not to be the case. Further, pressure from the whaling industry led to higher and higher quotas being set. The quota for the $1959 / 60$ season was set at 17,600 BWUs, meaning that as many as 17,600 blue whales, 35,200 fin whales, 44,000 humpback whales, 105,600 sei whales, or some combination of the four could be taken.

The whaling fleets raced to achieve the largest share possible of the permitted takes. Except for the Japanese, whose principal interest was the take of sei whales for human food, most fleets were principally interested in oil and preferentially searched for and took the larger blue, fin and humpback whales. Consequently, the already depleted Antarctic blue and humpback whale populations were further depleted, and overexploitation of fin and sei whales soon followed (McHugh 1974; McVay 1974; Gambell 1993; Gambell 1999).

In 1961, the IWC appointed a three person Scientific Committee (SC) of fishery biometricians, later expanded to four, to undertake an independent assessment of the status of the exploited Antarctic whale stocks, and to recommend measures to restore and maintain them at sustainable take levels. In their reports (Chapman and others 1964; Chapman and others 1965), the SC provided analyses indicating the precarious status of Antarctic populations of blue and humpback whales. They recommended a moratorium on the taking of those species. They also noted the need for more reliable information on the biology, demography and dynamics of the affected stocks. They recommended adoption of the concept of maximum sustainable yield (MSY) used in fishery management to estimate the sustainable catch levels for each species and stock. In partial response to the recommendations, the IWC established moratoria in 1963 and 1964 on the taking of Antarctic humpback and blue whales, respectively. However, no agreement could be reached on setting catch quotas for individual species and stocks.

Because of the IWC's continuing failure to effectively prevent the overexploitation of whale stocks, the 1972 United Nations' Stockholm Conference on the Human Environment adopted a resolution calling for a tenyear moratorium on all commercial whaling. Although some IWC members agreed a moratorium was warranted, the necessary three-quarters majority did not. In 1974, however, the IWC adopted what was called the New Management Procedure, whereby catch limits were to be established for individual stocks based on their status relative to their MSY levels, thought to be between 50 percent and 60 percent of their pre-exploitation population sizes. As explained by Holt and Young (1990) and Gambell (1999), each exploited or potentially exploited 
stock was to be assigned to one of three categories based on its current estimated size relative to its estimated MSY level: (1) Sustained Management Stocks whose current estimated sizes were between 10 percent below and 20 percent above their estimated MSY levels; (2) Initial Management Stocks whose current estimated sizes were more than 20 percent above their estimated MSY levels; and (3) Protected Stocks whose current estimated sizes were more than 10 percent below their estimated MSY levels. No takes of Protected Stocks were to be allowed to enable them to recover as rapidly as possible to their estimated MSY levels. Catch levels for Initial and Sustained Management Stocks were to be set to bring them to and to maintain them at their estimated MSY levels, respectively.

As Chapman (1976) indicated, it was thought that adoption of the New Management Procedure would prevent further overexploitation and enable recovery of depleted stocks. However, while conceptually reasonable, the procedure did not work, primarily because the available demographic and life history data were insufficient to enable the IWC's SC to unequivocally determine the current, pre-exploitation and MSY levels of the various stocks. This led in turn to differing views regarding the adequacy and interpretation of the available data, and enabled IWC member countries with vested economic interests in whaling to seek and secure catch quotas that ultimately proved to be unsustainable. Additionally, from the late 1950 s to the early 1970 s, the former Soviet Union substantially under-reported its whaling fleets' catches in the Southern Hemisphere, and both allowed and did not report catches of protected right, blue and humpback whales (Tormosov and others 1998; Brownell and others 2002; Clapham and Ivashchenko 2009; Gan 2011).

In the late 1960s and early 1970s, attitudes concerning whales and whaling began to change. Also, there was a growing awareness that living organisms interact with each other in complex ways and that single-species, MSY management was an outmoded management concept (see for example Holt and Talbot 1978). Additionally, a number of the IWC's member countries stopped whaling and there was an influx of new members with no interest in commercial whaling. Consequently, in 1982, the necessary three-quarters majority of IWC members agreed to a moratorium on commercial whaling, pending a comprehensive assessment of the status of the exploited whale stocks and development of a more effective and conservative regulatory regime.

The moratorium entered into force for the 1985/86 pelagic and the 1986 coastal whaling seasons. Since then, the IWC's SC has completed the status-of-stocks reviews, and recommended a Revised Management Procedure (RMP). The RMP was adopted by the IWC in 1994 (Young 1993; Gambell 1999). However, it has not been possible to get agreement on an observation and inspection system to ensure compliance with take levels that would be authorised under the RMP. Consequently, the moratorium remains in effect.
Furthermore, there is controversy concerning the possible resumption of commercial whaling. There is also controversy concerning limited commercial whaling being authorised by several IWC members in accordance with provisions of the 1946 ICRW. For example, Norway, which objected to the moratorium following its adoption, is not bound by it. Likewise, Iceland, which withdrew from and subsequently rejoined the IWC, filed a reservation to the moratorium when it rejoined and is not bound by it. Both countries have authorised and continue to authorise the taking by their nationals of limited numbers of minke whales (B. acutorostrata Lacépède) in the North Atlantic for commercial purposes. Japan, which initially filed an objection to the moratorium but subsequently withdrew it, has issued permits pursuant to Article VIII of the ICRW allowing its nationals to take limited numbers of minke whales and number of other species in the Antarctic and North Pacific for purposes of scientific research.

The research whaling being authorised by Japan has also generated much controversy (see for example Clapham and others 2003; Clapham and others 2006; Sand 2008; Corkeron 2009; Peace 2010; Clapham 2016). In 2013, Australia challenged Japan in the International Court of Justice (ICJ) arguing that Japan's authorisation of lethal taking of whales for purported scientific research served no legitimate scientific purpose. The Court's judgement (ICJ 2014), issued on 31 March 2014, found that the permits being issued by Japan were not for purposes of scientific research as provided for in Article VIII of the ICRW. Although it was expected that Japan would cease issuing permits for scientific whaling, it may be that the programme will be restructured and continued (Clapham 2015).

In recent years there also has been growing recognition that whales play important functional roles in the ecosystems of which they are part (Ballance and others 2006; Nicol and others 2010; Roman and others 2014; Surma and others 2014; Willis 2014). Furthermore, there has been growing awareness that whaling is not the only threat to whales and the ecosystems of which they are part (Halpern and others 2008; Halpern and others 2014; Clapham 2016). There are also indications that the economic value of watching live whales may be as great as or even greater than that of whales killed for commercial purposes (Kraus 1989; Barstow 1996; Cisneros-Montemayor and others 2010). In response, the IWC and its Scientific Committee have broadened their remit in recent years to include consideration of the threats to whales and marine ecosystems posed by such things as climate change, environmental pollution, ship strikes, entanglement in fishing gear, disease and competition with fisheries for the same prey species.

\section{Antarctic krill and krill fishing}

As indicated previously, the British FIDs administration took steps in the early 1900 s to regulate development of the South Georgia sealing and whaling industries. 
In addition, as described by Mackintosh (1950), an interdepartmental committee was established in London to consider ways to sustain the whaling industry and develop other industries in the FIDs. Among other things, the 1920 Report of the Interdepartmental Committee on Research and Development in the Dependencies of the Falkland Islands recommended development of a research programme to document the life histories of the whales and the key features of their oceanographic environment in the FIDs. In 1924, an executive committee was established to oversee implementation of the programme. The committee was named the Discovery Committee after Robert Falcon Scott's ship, Discovery, which was purchased and refitted as an oceanographic research vessel to carry out the recommended oceanographic studies. Discovery, a sailing ship, was augmented with a steam-powered ship, William Scoresby; however, it was replaced in 1929 by Discovery II, built explicitly for oceanographic research in the Southern Ocean.

A principal objective of the Discovery investigations was to determine the life history, demography, and factors affecting the distribution and abundance of Antarctic krill, Euphausia superba Dana, the principal food of many Antarctic baleen whales (Marr 1962; Deacon 1977). The overexploitation and decline of Southern Ocean stocks of krill-eating whales led to the development of the Krill Surplus Hypothesis in the 1960s, which posited that there were tens of thousands to more than a million tonnes of Antarctic krill previously consumed by whales that could be taken for commercial purposes (Gulland 1970; Mackintosh 1970; Moiseev 1970). In response to decreasing access to fishing grounds in growing numbers of coastal state waters, and declining fishery resources elsewhere on the high seas, vessels from the former Soviet Union and Japan initiated exploratory krill fishing in the Antarctic in the 1960s (Bakus and others 1978; Sahrhage 1984).

In addition to being the principal prey of several baleen whale species, Antarctic krill is the principal prey of crabeater seals, several species of penguins and flying birds, and several species of fish and squid. Some of these in turn are the principal prey of higher trophic level predators, such as killer whales, sperm whales and leopard seals. Therefore, if not regulated effectively, the krill fishery could adversely affect these species, as well as impede recovery of the depleted Southern Ocean stocks of krilldependent baleen whales. This possibility was recognised by the ATCPs and led to adoption of Recommendation VIII-10 at the 1975 Consultative Meeting (ATCM) in Oslo. Among other things, the recommendation requested that SCAR provide assessments of the available information and ongoing research regarding Antarctic krill and related components of the Antarctic marine ecosystem.

In response to the ATCP's request, SCAR organised and held a workshop in Woods Hole, MA, USA, in August 1976 where the relevant data were assessed and research needs identified. SCAR subsequently provided to the ATCPs a report that summarised the existing knowledge of the biology and ecology of Antarctic krill, identified critical uncertainties and research needs, and recommended a research programme entitled Biological Investigations of Marine Antarctic Systems and Stocks (BIOMASS) (SCAR/SCOR 1977).

The principal objective of the BIOMASS programme was to gain a deeper understanding of the structure and dynamic functioning of the Antarctic marine ecosystem as a basis for the future management of potential living resources'. Implementation of the programme began with the planning and conduct in 1980/81 of a multinational, multiship research effort entitled the First International BIOMASS Experiment (FIBEX). A second effort, SIBEX, was initiated in 1983/84 and continued in 1984/85. The former was a broad-scale acoustic survey to obtain better information on the distribution and abundance of Antarctic krill in the Southern Ocean. The objective of SIBEX was to begin to gain a better understanding of the dynamics of the krill-based Antarctic marine food web, particularly the relationship between the seasonal advance and retreat of the Antarctic sea ice, and the distribution and abundance of krill. El Sayed (1994) describes the history, organisation and accomplishments of the BIOMASS programme.

\section{The Convention on the Conservation of Antarctic Marine Living Resources}

Fishery-related issues also were considered at ATCM IX in London (19 September-7 October 1977). Recommendation IX-2 from that meeting called upon the ATCPs to conclude, as a matter of priority, a definitive regime for the conservation of Antarctic marine living resources. Australia subsequently offered to host a Special Consultative Meeting (SCM) to elaborate the regime. The first session of the SCM was held in Canberra (27 February-16 March 1978). A subsequent session was held in Buenos Aires (17-28 July 1978). Informal discussions were held in Washington DC (September 1978), Bern (March 1979) and during the ATCM X in Washington DC (17 September-5 October 1979). The concluding session, at which the Convention for the Conservation of Antarctic Marine Living Resources (CCAMLR) was signed, was in Canberra (7-20 May 1980). CCAMLR entered into force in April 1982 following ratification by eight (half plus one) of the 15 signatories.

The convention is unique in that it is a marine ecosystem conservation agreement, not a regional fishery management agreement. This is made clear in the Preamble as well as in Articles I and II of the convention. The Preamble's first paragraph recognises 'the importance of safeguarding the environment and protecting the integrity of the ecosystem of the seas surrounding Antarctica'. Article I defines Antarctic marine living resources as all living organisms and their interactions with each other and the physical environment in the marine area south of the Antarctic Convergence (now referred to as the Polar Front). Article II(1) states that ' $[t]$ he objective of this Convention is the conservation of Antarctic marine 
living resources' - that is, the conservation of all living organisms and their interactions with each other and the physical environment in the marine area south of the Polar Front.

To make it clear that the convention was not intended to exclude commercial fisheries, Article II(2) states that '[f]or the purposes of this Convention, the term 'conservation' includes rational use'. Article II(3) then provides principles of conservation for judging what constitutes rational use. It states that:

'[a]ny harvesting and associated activities in the area to which this Convention applies shall be conducted in accordance with the provisions of this Convention and with the following principles of conservation:

(a) prevention of decrease in the size of any harvested population to levels below those which insure its stable recruitment. For this purpose its size should not be allowed to fall below a level close to that which ensures the greatest net annual increment;

(b) maintenance of the ecological relationships between harvested, dependent and related populations of Antarctic marine living resources and restoration of depleted populations to levels defined in sub-paragraph (a) above; and

(c) prevention of changes or minimisation of the risk of changes in the marine ecosystem which are not potentially reversible over two or three decades [an approximation of a human generation], taking into account the state of available knowledge of the direct and indirect impact of harvesting, the effect of introduction of alien species, the effects of associated activities on the marine ecosystem and the effects of environmental changes, with the aim of making possible the sustained conservation of Antarctic marine living resources [and therefore maintain the fullest possible range of management options for future generations]'.

A Commission was established to implement CCAMLR and a Scientific Committee (SC-CAMLR) was also established to advise CCAMLR on measures needed to meet its objective and principles of conservation.

\section{The CCAMLR Ecosystem Monitoring Programme}

During the second meeting of the SC-CAMLR in 1983, possible means were considered for detecting the indirect effects of fisheries, particularly the krill fishery, on other ecosystem components. At its 1984 meeting, the SCCAMLR established an Ad Hoc Working Group on Ecosystem Management and agreed that the group should meet before its 1985 meeting to develop a recommended approach for meeting the ecosystem conservation objective of the convention. The intercessional meeting was held in Seattle, WA, USA, in May 1985. The report of the meeting (SC-CCAMLR-IV/07) led, among other things, to the establishment of the CCAMLR Ecosystem Monitoring Programme (CEMP) focused principally in the Antarctic Peninsula Region and Scotia Sea where most krill fishing has occurred.

Agnew (1997) reviewed the intent and subsequent development of the CEMP. Miller (2002) describes the development of the management approach to the krill fishery and associated ecosystem components from 1985 to 1995. Additional information concerning these and other actions by CCAMLR and SC-CAMLR can be found on the website maintained by the Convention Secretariat (https://www.ccamlr.org).

\section{Regulation of the krill fishery}

As indicated in the CCAMLR and SC-CAMLR meeting reports, a series of steps have been taken to assess and minimise the risk that the krill fishery will have adverse effects on either the krill resource or on dependent and ecologically related species and populations. However, as Miller (2002) and others point out (see for example Nicol and de la Mare 1993; Nicol and Endo 1999; Parkes 2000; Constable 2002; Atkinson and others 2009; Reid and others 2010; Atkinson and others 2012; Koch and others 2012), there are multiple uncertainties concerning the distribution, movement, size and productivity of the krill resource, and its numerical and functional relationships with other ecosystem components. There are also significant uncertainties concerning the effects of annual variation in sea ice and other environmental conditions on the krill resource and associated biota. Consequently, as a practical matter, the SC-CAMLR has developed and adopted a set of decision rules and simulation models for estimating and providing advice to CCAMLR on 'precautionary' catch limits for Antarctic krill and targeted fish species.

Constable and others (2000) describe the development and rationale for the decision rules, and indicate that they are intended to provide a practical means for implementing the convention when the available data are insufficient to unequivocally determine regulatory measures necessary to meet the Article II(3) conservation principles. The central tenet of the decision rule regarding Antarctic krill is that limiting the authorised take level to no more than 25 percent of the estimated pre-exploitation spawning biomass will enable 75 percent escapement to allow the suite of krill predators, including depleted stocks of krill-dependent baleen whales, to be restored to and/or maintained at or near their maximum net productivity levels as called for in Article II(3)(b). However, I have found no indication in any publicly available document whether the intended 75 percent escapement was chosen arbitrarily in recognition of the central role of krill in the Antarctic marine ecosystem, or was determined based on estimation of the amount of krill needed to restore or maintain the suite of krill predators at or near their maximum net productivity levels. Furthermore, I have not found any publicly available documentation indicating (1) the assumptions inherent in the decision rule and modelling being used to make the allowable take determinations; (2) the possible consequences, if any, if the assumptions are not valid; or (3) research and monitoring being done 
to validate the assumptions. Consequently, it is at best questionable whether the management of the krill fishery is and will continue to be appropriately conservative or precautionary with regard to the objective of the convention and the Article II(3) principles of conservation.

On a related matter, selected colonies of land-breeding krill-dependent fur seals, penguins and flying birds are being monitored as part of the CEMP in the Antarctic Peninsula Region and Scotia Sea. For practical reasons (see below), monitoring of the recovery status of critically endangered blue whales and other depleted populations of krill-dependent whales was not made part of the CEMP. However, there have been a number of CCAMLRindependent studies indicating that krill-dependent whales inhabit and feed on the high density krill swarms in the same areas where the krill fishery occurs (Reid and others 2004; Friedlaender and others 2006; Friedlaender and others 2008; Wiedenmann and others 2011; Braithwaite and others 2015). Consequently, the fishery may be competing with and affecting krill-dependent whales more than the land-breeding colonies of fur seals, penguins and flying birds being monitored. Also, while crabeater seals were identified in the 1984 workshop report as a potential indicator of the indirect effects of the krill fishery, they principally inhabit pack ice areas where they are difficult to survey and where fishing is limited. Therefore, they were not included in the CEMP. However, there now are indications that crabeater seals in the Antarctic Peninsula Region may be being affected by the krill fishery (Forcada and others 2012).

Further, it is clear that climate change is affecting sea ice, water temperature and other environmental conditions in the Southern Ocean, including areas around the Antarctic Peninsula and the Scotia Arc where most krill fishing has been focused (Ducklow and others 2007; Nicol and others 2008; Forcada and others 2012). It is also likely that these environmental changes are affecting the krill resource and other components of the krill-centred food web in ways that may exacerbate the effects of the fishery (Nicol and others 2008). However, while the CCAMLR and SC-CAMLR meeting reports indicate that climate change is of concern, it appears that there is no agreement on what could and should be done to differentiate its effects from the effects of the fishery. Likewise, it appears that there is no agreement on the need for CCAMLR-related climate change research and monitoring, or how management of the krill fishery or other fisheries may need to be changed to account for the effects of climate change (see for example Bloom 2015 and the 2015 CCAMLR meeting reports, https://www.ccamlr.org/en/meetings/meetings).

It is important to recognise that commercial fisheries constitute new predators that compete with and can often out-compete natural predators for prey species such as krill (Darimont and others 2015). To date, the annual fishery catches of Antarctic krill in the Antarctic Peninsula Region and Scotia Sea have been a small fraction of the estimated pre-fishery krill spawning biomass in the region. The lack of substantial growth of the fishery has been largely due to the paucity of markets for krill and related products. However, there now appear to be growing markets for krill in the global fish farming and pharmaceutical industries (Nicol and Foster 2003; Schurmeir 2010). Therefore, it seems probable that there will be growing interest in the krill fishery (see for example Hill and others 2014), and possible pressure by the fishing industry to increase the authorised catch levels to meet the market demands even though there remains substantial uncertainty concerning the combined effects of the fishery and climate change on the krill resource and on ecologically related species and populations.

Furthermore, some members of CCAMLR and SCCAMLR appear to be interpreting the reference to 'rational use' in Article II(2) differently than intended in 1980 when the negotiation of the convention was concluded. That is, some members are apparently interpreting Article II(2) to mean that fisheries should be unregulated unless there is compelling evidence that they are having effects contrary to the Article II(3) principles of conservation. Contrary to what was intended, this interpretation appears to have led to a compromise and de facto amendment of the convention that there somehow should be a balance between resource and ecosystem conservation and fishery regulation (see for example Constable and others 2000; Hill and others 2014; ASOC 2015).

Because the decisions of the Commission on matters of substance require the consensus of all its members, as few as one or two members can block establishment of conservation measures limiting fishing seasons, catch levels, creation of special research or management areas, and other measures judged necessary by the majority to ensure that fisheries and associated activities do not have effects contrary to the objective of the convention and the Article II(3) principles of conservation. Consequently, if market demand for krill grows substantially, a minority of CCAMLR members with vested interests in the economic benefits of the fishery could elect to block further efforts to regulate the fishery, at least until there is compelling evidence that the fishery has had or is having effects contrary to the Article II(3) principles of conservation. If this happens, as happened previously with efforts to effectively regulate commercial whaling, it is unlikely that anything could be done to restore the krill resource or affected krill-dependent species and populations to their pre-exploitation levels within 20-30 years as called for by CCAMLR Article II(3)(c).

\section{Summary and discussion}

Exploitation of fur and elephant seals in the Antarctic in the late 1700 s and early 1800 s was unregulated, driven by market demands and led to the near extinction of both species. Although there were multiple efforts to regulate commercial whaling in the Antarctic and elsewhere, the efforts failed to prevent the overexploitation and depletion of all Southern Ocean stocks of large whales, except 
the minke whale. The ATCPs that negotiated CCAMLR recognised that krill is a keystone species in the Antarctic marine ecosystem. They also recognised that the singlespecies fishery management concept of MSY failed to take into account the possible effects of fisheries and associated activities on ecosystem components other than the species and populations targeted by the fisheries. Consequently, while the convention defines conservation to include rational use of marine living resources in the Convention Area, it provides in Article II(3) principles of conservation for judging what constitute rational use.

If not effectively regulated to meet the Article II(3) principles of conservation, the Antarctic krill fishery, combined with climate change, is likely to cause significant, possibly irreversible declines in the distribution, abundance and productivity of the krill resource. Any such declines would in turn have adverse effects on krilldependent and ecologically related species and populations, including preventing or impeding the recovery of depleted populations of krill-dependent whales. These possibilities have been recognised by both the IWC and SC-CAMLR, and cooperative efforts have been initiated to identify measures necessary to minimise the risk of significant adverse population or ecosystem effects. Among other things, the IWC's SC has proposed, and the SC-CAMLR has agreed, to hold a joint workshop on multispecies ecosystem modelling. A Working Group was established in 2014 to plan the workshop, and draft terms of references were agreed in 2015 (IWC 2015; SC-CAMLR 2015). The final terms of reference, format, and time and place for the workshop have yet to be agreed.

From the publicly available information, it is not clear what topics the workshop is intended to address. If not on the workshop agenda, or already being done, the following are some additional tasks that the two committees could work together to accomplish:

- Estimate the amount of krill required to enable depleted stocks of krill-dependent whales to be restored and maintained near their greatest annual recruitment levels as called for by CCAMLR Article II(3)(b);

- Assess the effect that recovery of depleted whale stocks would have on the amount of krill available for human uses;

- Determine actions necessary to differentiate the effects of the krill fishery from the effects of climate change on the distribution, abundance and productivity of Antarctic krill; and

- Review the decision rule, data and modelling being used to estimate the allowable fishery catches of krill to determine if they are appropriately precautionary with regard to the CCAMLR Article II(3) principles of conservation for judging rational use.

The most effective way to minimise the risk that the fishery and climate change may be adversely affecting the krill resource and recovery of depleted stocks of krill- dependent whales would be to conduct appropriately designed synoptic surveys at regular intervals (for example every 5,7 , or 10 years) to detect changes and trends in the distribution and abundance of both krill and krilldependent whales in areas where krill fishing is occurring and likely to occur in the foreseeable future. This would enable detection of declines in the krill resource and associated changes in the demographics of krill-dependent whales in time to take remedial action if necessary to prevent significant adverse changes. To minimise the risk of long-term or irreversible adverse effects, it would be reasonable, except in cases where there is compelling contrary evidence, to require that no increases in the authorised catch levels of krill or changes in fishing methods or seasons be allowed in the intervals between the synoptic surveys.

If management of the fishery based on the results of regular synoptic surveys is not possible for financial or other reasons, a number of other steps could reasonably be taken by the CCAMLR, in consultation with the IWC, to reduce the risk that the fishery and climate change will cause significant declines in the krill resource and the corresponding effects on the recovery of depleted whale populations. For example, while means for monitoring the distribution and abundance of whales to detect possible fishery-caused changes were limited when the CEMP was being developed in the 1980s, this is no longer the case. That is, the following could be done now to assess and monitor the distributions and abundance of krill-dependent whales in areas where they are competing with and could be affected by the krill fishery:

- Train and require that cetacean observers be carried on all krill fishing vessels to record and report the species, numbers, adult/calf ratios and behaviour of cetaceans visible from the vessels during fishing operations and travel to, from and on the fishing grounds;

- Expand the existing cetacean photo-identification and assessment programmes to obtain and utilise photographs taken by passengers and crews on tourist vessels operating in the Antarctic Peninsula Region and Scotia Sea. Toward this end (1) develop a brochure indicating the kinds of photographs wanted, how they will be used, where they should be sent, and what date, time, location and other data should be sent with them; (2) consult with the International Association of Antarctica Tour Operators (IAATO) to determine how the brochures can best be formulated and provided to tour operators, tour ships and tourists to obtain useful photographs and related date, time and location data; and (3) develop a feedback system to acknowledge receipt of useful photographs and encourage tour operators and passengers to participate in the programme; and

- Establish a network of passive acoustic recorders to detect and monitor the vocalisations and the presence and relative abundance of different whale species in 
areas where the fishery may be competing with them for krill.

\section{Acknowledgements}

I thank Christopher Wilson for encouraging me to write this paper and for advising me of Barrett-Hamilton's journal describing his observations of whaling operations at South Georgia in 1914. I also thank four anonymous reviewers and the following individuals for reviewing and commenting on earlier drafts of this paper: David Ainley, Claire Christian, R. Tucker Scully, Donald Siniff, Peter Thomas and Michel Tillman. Finally, I thank Rebecca Lent, the Executive Director of the US Marine Mammal Commission, for providing me office space and access to the Commission's digital library to write this paper.

\section{References}

Agnew, D. 1997. Review: the CCAMLR Ecosystem Monitoring Programme. Antarctic Science 9: 235-242.

Ainley, D.G. 2010. A history of the exploitation of the Ross Sea, Antarctica. Polar Record 45(238): 233-243.

Anonymous. 1970. Preface to part VII - The biology of seals. In: Holdgate, M.W. (editor). Antarctic Ecology (Volume 1). London and New York: Academic Press.

Anonymous. 1988. Report of the 1988 meeting to review the operation of the Convention for the Conservation of Antarctic Seals, London 12-16 September. In: Handbook of the Antarctic Treaty System (9th edition, July 2002). Washington, DC: US Department of State: $340-348$.

ASOC (Antarctic and Southern Ocean Coalition). 2015. Implementing Article II of the CAMLR Convention. CCAMLRXXXIV/BG/25.

Atkinson, A., S. Nicol, S. Kawaguchi and others. 2012. Fitting Euphasia superba into Southern Ocean food web models: a review of data sources and their limitations. CCAMLR Science 19: 219-245.

Atkinson, A., V. Siegel, E.A. Pakhomov and others. 2009. A reappraisal of the total biomass and annual production of Antarctic krill. Deep-Sea Research 1 - Oceanographic Research Papers 56: 727-740.

Bakus, G.J., W. Garling and J.F. Buchanan. 1978. The Antarctic krill resource: prospects for commercial exploitation. Prepared by Tetra Tech for the US Department of State. Contract 1722-720188.

Ballance, L.T., R.L. Pittman, R.P. Hewitt, D.B. Siniff, W.Z. Trivelpiece, P.J. Clapham and R.L. Brownell. 2006. The removal of large whales from the Southern Ocean: evidence for longterm ecosystem effects. In: Estes, J.A., D.P. DeMaster, D.F Doak, T.M. Williams and R.L. Brownell (editors). Whales, whaling, and ocean ecosystems. Oakland, CA: University of California Press: 215-230.

Barstow, R. 1996. Non-consumptive utilization of whales. Ambio 15(3): 4-12.

Beaglehole, J.C. (editor). 1955. The journals of Captain James Cook on his voyages of discovery. Cambridge: Halduyt Society.

Bloom, E., J. Mundy and F. Berguño. 2015. Report of the cochairs of the CCAMLR symposium, 5-8 May 2015, Santiago, Chile. CCAMLR-XXXIV/28 Rev2.

Bonner, W.N. 1958. Exploitation and conservation of seals in South Georgia. Oryx 4(6): 373-380.
Bonner, W.N. 1964. Population increase in the fur seal, Arctocephalus tropicalis gazella, at South Georgia. In: Carrick, R., M. Holdgate and J. Prevost (editors). Biologic Antartique: proceedings of the first SCAR symposium on Antarctic biology (Volume 2). Paris: Hermann: 433-443.

Bonner, W.N. 1984. Conservation and the Antarctic. In: Laws, R.M. (editor). Antarctic ecology. London and New York: Academic Press: 821-850.

Bonner, W.N. and R.M. Laws. 1964. Seals and sealing. In: Priestly, R., R.J. Adu and G. du Q. Robin (editors). Antarctic research. London: Butterworth: 163-190.

Boyd, L.L., T.R. Walker and J. Poncet. 1996. Status of southern elephant seals at South Georgia. Antarctic Science 8(3): 237-244.

Braithwaite, J.R., J.J. Meeuwig, T.B. Letessier and others. 2015. From sea ice to blubber: linking whale condition to krill abundance using historical whaling records. Polar Biology 38(8): 1195-1202.

Brownell, R.L. Jr. and A.V. Yablokov. 2002. Illegal and pirate whaling. In: Perrin, W.F., B. Wursig and H. Thewissen. (editors). Encyclopedia of marine mammals. San Diego, CA: Academic Press: 608-612.

CCAMLR (Convention on the Conservation of Antarctic Marine Living Resources) of 20 May 1980 (1329 UNTS 48).

Chapman, D.G., K.R. Allen and S.J. Holt. 1964. Report of the committee of three scientists on the special scientific investigation of the Antarctic whale stocks. Reports of the International Whaling Commission 14: 32-106.

Chapman, D.G., K.R. Allen, S.J. Holt and J.A. Gulland. 1965. Report of the committee of four scientists. Reports of the International Whaling Commission 15: 47-63.

Chapman, D.G. 1976. The future of the great whales. Puget Soundings March: 18-20.

Cisneros-Montemayor, A.M., U.R. Sumaila, K. Kaschner and other. 2010. The global potential for whale watching. Marine Policy 14: 1273-1278.

Clapham, P.J. 2015. Japan's whaling following the International Court of Justice ruling: brave new world or business as usual. Marine Policy 51: 38-41.

Clapham, P.J. 2016. Managing leviathan: conservation challenges for the great whales in a post-whaling world. Oceanography 29(3): 214-225.

Clapham, P.J., P. Bergoren, S. Childerhouse and others. 2003. Whaling as science. Bioscience 53(3): 210-212.

Clapham, P.J., S. Childerhouse, N.J. Gales and others. 2006. The whaling issue: conservation, confusion, and casuistry. Marine Policy 31: 314-319.

Clapham, P. and Y. Ivashchenko. 2009. A whale of a deception. Marine Fisheries Review 71(1): 44-52.

Constable, A.J. 2001. The ecosystem approach to managing fisheries: achieving conservation objectives for predators of fished species. CCAMLR Science 8: 37-64.

Constable, A.J., W.K. de la Mare, D.J. Agnew, I. Everson and D. Miller. 2000. Managing fisheries to conserve the Antarctic marine ecosystem: practical implementation of the Convention on the Conservation of Antarctic Marine Living Resources (CCAMLR). ICES Journal of Marine Science 57: 778-791.

Corkeron, P.J. 2009. As I see it: reconsidering the science of scientific whaling. Marine Ecosystem Progress Series 375: 305-309.

Darimont, C.T., C.H. Fox, H.M. Bryant and T.E. Reimechen. 2015. The unique ecology of human predators. Science 34: 9858859.

Deacon, G.E.R. 1977. The Southern Ocean history of exploration. In: Llano, G.A. (editor). Adaptations within Antarctic 
ecosystems: proceedings of the third SCAR symposium on Antarctic biology. Washington, DC: Smithsonian Institution Press: $x v-x x x v i i$.

Ducklow, H.W., K. Baker, D.G. Martinson and others. 2007. Marine pelagic ecosystems: the west Antarctic Peninsula. Philosophical Transactions of the Royal Society B362: 6794.

El Sayed, S.Z. 1994. History, organization and accomplishments of the Biomass programme. In: El Sayed, S.Z. (editor). Southern Ocean ecology: the BIOMASS perspective. Cambridge: Cambridge University Press: 1-8.

Erickson, A.W. and R.J. Hofman. 1974. Antarctic seals. In: Bushnell, V. (editor). Antarctic mammals. Antarctic Map Folio Series No. 18. New York, NY: American Geographical Society: 4-13.

Forcada, J., P.N. Trathan, P.L. Boveng and others. 2012. Responses of Antarctic pack ice seals to environmental change and increasing krill fishing. Biological Conservation 149: 140-150.

Francis, D. 1990. A history of world whaling. London: Penguin Books.

Friedlaender, A.S., W.R. Fraser, D. Patterson and others. 2008. The effects of prey demography on humpback whale (Megaptera novaeangliae) abundance around Anvers Island, Antarctica. Polar Biology 31(10): 1217-1224.

Friedlaender, A.S., P.N. Halpin, S.S. Qian and others. 2006. Whale distribution in relation to prey abundance and oceanographic processes in shelf waters of the western Antarctic Peninsula. Marine Ecology Progress Series 317: 297310.

Gambell, R. 1993. International management of whales and whaling: an historical review of the regulation of commercial and aboriginal subsistence whaling. Arctic 40(2): 97-107.

Gambell, R. 1999. The International Whaling Commission and the contemporary whaling debate. In: Twiss, J.R., Jr. and R.R. Reeves (editors). Conservation and management of marine mammals. Washington, DC: Smithsonian Institution Press: $179-198$

Gan, I. 2011. The first practical Soviet steps toward getting a foothold in the Antarctic: the Soviet Antarctic whaling flotilla Slava. Polar Record 47(240): 21-28.

Gulland, J.A. 1970. The development of the resources of the Antarctic seas. In: Holdgate, M.W. (editor). Antarctic Ecology (Volume 1). London and New York: Academic Press: 217223.

Halpern, B.S., C. Longo, D. Hardy and others. 2012. An index to assess the health and benefits of the global ocean. Nature 488: 616-620.

Halpern, B.S., S. Walbridge, K.A. Selkoe and others. 2008. A global map of human impact on marine ecosystems. Science 319: 948-952.

Hewitt, R.P., J. Watkins, M. Naganobu and others. 2004. Biomass of Antarctic krill in January/February 2000 and its use in revising an estimate of precautionary yield. Deep-Sea Research II - Topical Studies in Oceanography 51: 1215-1236.

Hill, S., R. Cavanagh, C. Knowland, S. Grant and R. Downing (editors). 2014. Bridging the krill divide: understanding cross-sector objectives for krill fishing and conservation. Report from the ICED-BAS-WWF workshop, 9-10 June 2014, WWF's Living Planet Center, Woking, UK.

Hofman, R.J. 1985. The Convention on the Conservation of Antarctic Marine Living Resources. In: Alexander, L.M. and L. Carter Hanson (editors). Antarctic politics and marine resources: critical choices for the 1980s. Kingston, RI: Center for Ocean Management Studies, University of Rhode Island: 113-122.
Hollenberg, M. 2008. For the love of nature: mammals described and illustrated by the naturalists Gerald E.H. Barrett-Hamilton and Edward Adrian Wilson. Vancouver, BC: University of British Columbia: Appendix 1.

Holt, S.J., and L.M. Talbot. 1978. New principles for the conservation of wild living resources. Wildlife Monographs 59: 3-33.

Holt, S., and N.M. Young. 1990. Guide to review of the management of whaling. Washington, DC: Center for Marine Conservation.

ICJ (International Court of Justice). 2014. Judgment: whaling in the Antarctic (Australia v. Japan: New Zealand intervening). ICJ Reports 2014. URL: http://www.icj-cij.org/docket/index. php?p1 $=3 \&$ p2 $=1 \&$ case $=148 \&$ code $=a j \& p 3=4$ (accessed 9 November 2016).

ICRW (International Convention for the Regulation of Whaling) of 2 December 1946 (161 UNTS 72).

IWC (International Whaling Commission). 2015. Report of the working group on ecosystem modeling. IWC/66/Rep01: Annex 1

Koch, K.H., E. Barrera-Oro, M. Belchier and others. 2012. The role of fish as predators of krill (Euphasia superba) and other pelagic resources in the Southern Ocean. CCAMLR Science 19: $115-179$

Kraus, S.D. 1989. Whales for profit. Whalewatcher 23(2): 18-29.

Landis, J. 2001. Antarctica, exploring the extremes: 400 years of adventure. Chicago, IL: Review Press.

Laws, R.M. 1977. Seals and whales in the Southern Ocean. Philosophical Transactions of the Royal Society B279: 8196.

Laws, R.M. 1994. History and present status of southern elephant seal populations. In: Le Boeuf, B.J. and R.M. Laws (editors). Elephant seals: population ecology, behaviour, and physiology. Berkley, CA: University of California Press: 4965.

Mackintosh, N.A. 1950. The work of the Discovery Committee. Proceedings of the Royal Society of London B137: 137-152.

Mackintosh, N.A. 1970. Whales and krill in the Twentieth Century. In: Holdgate, M.W. (editor). Antarctic Ecology (Volume 1). London and New York: Academic Press: 195-212.

MMC (Marine Mammal Commission). 1994. The Marine Mammal Commission compendium of selected treaties, international agreements, and other relevant documents on marine resources, wildlife, and the environment (Volume 2). Washington, DC: Marine Mammal Commission.

MMC (Marine Mammal Commission). 1997. The Marine Mammal Commission compendium of selected treaties, international agreements, and other relevant documents on marine resources, wildlife, and the environment (1st update). Washington, DC: Marine Mammal Commission.

MMC (Marine Mammal Commission). 2000. The Marine Mammal Commission compendium of selected treaties, international agreements, and other documents on marine resources, wildlife, and the environment (2nd update). Bethesda, MD: Marine Mammal Commission.

Marr, J.S.W. 1962. The natural history and geography of the Antarctic krill (Euphausia superb Dana). Discovery Reports 32: 433-464

McHugh, J.L. 1974. The role and history of the International Whaling Commission. In: Schevill, W.E. (editor). The whale problem: a status report. Harvard University Press: 305-335.

McVay, S. 1974. Reflections on the management of whaling. In: Schevill, W.E. (editor). The whale problem: a status report. Cambridge, MA: Harvard University Press: 369-382.

Miller, D.G.M. 2002. Antarctic krill and ecosystem management - from Seattle to Siena. CCAMLR Science 9: 175-212. 
Moiseev, P.A. 1970. Some aspects of the commercial use of the krill resources of the Antarctic seas. In: Holdgate, M.W. (editor). Antarctic Ecology (Volume 1). London and New York: Academic Press: 213-216.

Murphy, R.C. 1947. Logbook for Grace. London: Robert Hale.

Nicol, S., A. Bowie, S. Jarman and others. 2010. Southern Ocean iron fertilization by baleen whales and Antarctic krill. Fish and Fisheries 11: 203-209.

Nicol, S. and W. de la Mare. 1993. Ecosystem management and the Antarctic krill. American Scientist 81: 36-47.

Nicol, S. and Y. Endo. 1999. Krill fisheries: development, management and ecosystem implications. Aquatic Living $R e$ sources 23(2): 105-120.

Nicol, S. and J. Foster. 2003. Recent trends in the fishery for Antarctic krill. Aquatic Living Resources 16: 42-45.

Nicol, S., A. Worby and R. Leaper. 2008. Changes in the Antarctic sea ice ecosystem: potential effects on krill and baleen whales. Marine and Freshwater Research 59: 361-382.

Ommanney, F.D. 1971. Lost leviathan: whales and whaling. New York, NY: Dodd, Mead and Co.

Øritsland, T. 1970. Sealing and seal research in the southwest Atlantic pack ice, September-October 1964. In: Holdgate, M.W. (editor). Antarctic Ecology (Volume 1). London and New York: Academic Press: 367-374.

Parkes, G. 2000. Precautionary fisheries management: the CCAMLR approach. Marine Policy 24: 83-91.

Peace, A. 2010. The whaling war: conflicting cultural perspectives. Anthropology Today 26(3): 5-9.

Reid, K., M. Sims, R.W. White and K.W. Gillon. 2004. Spatial distribution of predator/prey interactions in the Scotia Sea: implications for measuring predator/fisheries overlap. DeepSea Research II - Topical Studies in Oceanography 51 1383-1396.

Reid, K., J.L. Watkins, E.J. Murphey and others. 2010. Krill population dynamics at South Georgia: implications for ecosystem-based fisheries management. Marine Ecology Progress Series 399: 243-252.

Roman, J., J.A. Estes, L. Morissette and others. 2014. Whales as marine ecosystem engineers. Frontiers in Ecology, Environment 12(7): 377-385.

Ross, J.R. 1847. A voyage of discovery and research in the southern and Antarctic regions during the years 1839-43. Reprinted, 1969. London: Latimer, Trend and Co.

Rubin, J. 2008. Antarctica (4th edition). Melbourne: Lonely Planet Publications.

Poncet, S. and K. Crosbie. 2005. A visitor's guide to South Georgia. Princeton, NJ: Princeton University Press.

Sahrhage, D. 1984. Fisheries overview. In: Alexander, L.M. and L. Carter Hanson (editors). Antarctic politics and marine resources: critical choices for the 1980s. Kingston, RI: Center for Ocean Management Studies, University of Rhode Island: 101-112.

Sand, P.H. 2008. Japan's 'research whaling' in the Antarctic Southern Ocean and the North Pacific Ocean in the face of the Endangered Species Convention (CITES). RECIEL 17(1): 56-71.
SCAR (Scientific Committee on Antarctic Research). 1991. Report of the workshop on southern elephant seals, 22-23 May 1991. Cambridge: Scientific Committee on Antarctic Research.

SCAR/SCOR (Scientific Committee on Antarctic Research/ Scientific Committee on Ocean Research). 1977. Biological investigations of marine Antarctic systems and stocks (BIOMASS) (Volume 1). Research proposals. Cambridge: Scott Polar Research Institute.

SCAR (Scientific Committee on Antarctic Research). 2006. Proposal to delist Antarctic fur seals as a specially protected species. ATCM XXXIX Working Paper 39.

SC-CAMLR. 2015. Joint SC-CAMLR and SC-IWC workshop its format and draft terms of reference. SC-CAMLRXXXIV/BG/33.

Schurmeir, Q. 2010. Ecologists fear Antarctic krill crisis. Nature 467: 15.

Sergeant, D.E. 1963. Harp seals and the sealing industry. Canadian Audubon 35(2): 29-35.

Sergeant, D.E. 1965. Exploitation and conservation of harp and hood seals. Polar Record 12(80): 541-551.

Small, G.I. 1971. The blue whale. New York, NY: Columbia University Press.

Stackpole, E.A. 1953. Chapter XII: Whales, sea-elephants and fur seals. In: Stackpole, E.A. (editor). The sea-hunters: the New England whalemen during two centuries, 1635-1835. Philadelphia, PA: J.B. Lippincott.

Surma, S., E.A. Pakhomov and T.J. Pitcher. 2014. Effects of whaling on the structure of the Southern Ocean food web: insights on the 'krill surplus' from ecosystem modelling. PLoS ONE 9(12): e114978. doi: 10.1371/journal.pone.0114978.

Tønnessen, J.N. and A.O. Johnson. 1982. The history of modern whaling. Berkeley, CA: University of California Press.

Tormosov, D.D., Y.A. Mikhalev, P.B. Best and others. 1998 Soviet catches of southern right whales, Eubalaena australis, 1951-1971: biological data and conservation implications. Biological Conservation 86: 185-197.

Villiers, A.J. 1925. Whaling in the frozen south: being the story of the 1923-24 Norwegian whaling expedition to the Antarctic. Indianapolis, IN: Bobbs-Merrill.

Weddell, J. 1825. A voyage toward the South Pole, performed in the years 1822-1824. London: Longman, Hurst, Tees, Orme, Brown and Green. (Reprinted 1970, London: David and Charles Reprints).

Wiedenmann, J., K.A. Cresswell, J. Goldbogen and others. 2011. Exploring the effects of reductions in krill biomass in the Southern Ocean on blue whales using a state- dependent foraging model. Ecological Modelling 222: 33663379.

Willis, J. 2014. Whales maintained a high abundance of krill: both are ecosystem engineers in the Southern Ocean. Marine Ecology Progress Series 513: 51-69.

Young, N.M. (editor). 1993. Examining the components of a Revised Management Scheme. Washington, DC: Center for Marine Conservation. 